\title{
Fuzzy Inference System Based Distance Estimation Approach for Multi Location and Transforming Phase to Ground Faults in Six Phase Transmission Line
}

\author{
A Naresh Kumar ${ }^{1}$, M Chakravarthy ${ }^{2}$ \\ ${ }^{1}$ Department of Electrical and Electronics Engineering, GITAM University, \\ Hyderabad, Telangana, India \\ E-mail: ankamnaresh29@gmal.com \\ ${ }^{2}$ Department of Electrical and Electronics Engineering, Vasavi College of Engineering, \\ Hyderabad, Telangana, India \\ E-mail: chakri4330@gmail.com
}

Received 31 October 2017

Accepted 1 March 2018

\begin{abstract}
The faults occurring in different phases at multiple locations and different times are difficult to locate exact location using conventional techniques. This paper develops a fault location estimation approach using fuzzy inference system for multi location phase to ground faults and transforming phase to ground faults in six phase transmission (SPT) line. The six phase current data of SPT line are generated by MATLAB software and processed through butter worth filter, sampling and discrete fourier transform for distance locator. The proposed technique is dependent on single terminal data only. Mamdani fuzzy inference system is employed to make decision. Triangular membership functions are used to design input-output fuzzy sets. Fuzzy inference system has been deployed for the fault distance location using IF-THEN rules. The proposed technique is validated during different multi location and transforming phase to ground faults with wide variations in fault resistance and fault inception angle. Simulations and calculations with MATLAB prove that the fault location method is correct and accurate.
\end{abstract}

Keywords: Fault location, Fuzzy inference system, Six phase transmission line.

\section{Introduction}

Indeed, a power transmission line is an important part of the power system. The existing power transmission capacity has to increase for facilitate the growing electrical energy demand. Therefore, a six phase transmission (SPT) system is considered as a best solution for power demand problems. SPT line carries power up to 73.2 percent more than double circuit three phase transmission (DCTPT) lines for the same power transmission right of way. SPT system also offers several benefits over three phase transmission (TPT) system such as lower audible noise levels, lesser corona, decreased radio interference levels, reduced conductor surface gradient, good voltage regulation, higher efficiency, better surge impedance loading and thermal loading capacity. The SPT line theory and benefits are demonstrated in the literature ${ }^{1,2,3,4,5,6}$. The DCTPT line is converted into a single circuit SPT line successfully ${ }^{7}$. The New York State Electric and Gas Corporation (NYSEG) made high phase order transmission project. This experimental system has innovated the model and operation of SPT system. A short transmission line i.e., $93 \mathrm{kV}$, SPT line with line length $2.4 \mathrm{~km}$ between Goudey and Oakdale was reconstructed from the NYSEGs $115 \mathrm{kV}$, DCTPT line configuration. The line was conducted in SPT line configuration for the period of three years. In NYSEGs project relays used is current differential, directional comparison, distance and microprocessor relays $8,9,10$ but not successful. Therefore, SPT line was restored to $115 \mathrm{kV}$, DCTPT line configurations. SPT line faults are 
analyzed in $\operatorname{Ref}^{11,12,13,14}$. In a SPT line possible phase to ground fault combination are 63 whereas it is only 7 in a TPT line. So protection scheme for SPT line is more complex as compared to a TPT line. Thus, fast protection approach is needed for faults occurrence to minimize the power system damage.

In $\operatorname{Ref}^{15,16,17,18}$, different location schemes for shunt faults have been explored using the currents and voltages on single end of transmission line. Some protection strategies use only the fault currents ${ }^{19,20,21}$. As reported in the literature ${ }^{22,23,24,25}$, many fault location procedures were addressed particularly for SPT lines. Earlier, the first-zone distance relaying algorithm has been used for cross country non-earthed faults protection in parallel transmission lines with successful results ${ }^{26}$. Furthermore, same approach for cross country ground faults in parallel transmission lines has been adopted in ${ }^{27}$. In addition to the first-zone distance relaying algorithm, some other techniques have also presented to evaluate cross-country faults ${ }^{28,29}$. Aleena and Yadav ${ }^{30}$ reported an overview of multi location and transforming faults location in thyristor controlled series capacitor compensated transmission line based on artificial neural network (ANN). However, the above techniques suffer from some deficiencies, such as inaccuracies, requires both terminal data. Meanwhile, fuzzy logic method plays a vital role in the fault location determination. From the open literature survey, it is well known that fuzzy based fault location which does not need data from receiving terminal have already been applied $^{31,32}$.

Although, there are a few studies that demonstrates the protection of multi location and transforming phase to ground faults it remains a main challenge in SPT line. As the number of phases increases, the associated faults are also increased and to protect the system becomes a cumbersome task. This issue is tricky because different phase to ground faults occurring at different location in different phases may yield similar results. To complement earlier techniques, this paper presents a novel multi location and transforming phase to ground fault location method for SPT line using fuzzy inference system (FIS). Earlier techniques usually require measurements recorded from two terminals of the faulted line. When the communication link fails in case of two terminal data used, backup protection is required. To overcome this problem, single end fundamental component currents have been utilized.
This paper is structured into 5 sections; the section 1 is an introduction. Section 2 explains SPT line configuration, modeling and simulation of multi location and transforming phase to ground faults. After that, fuzzy description is devoted and modeling of the FIS is given in section 3. In section 4, the summarized results are presented and discussed. Finally, section 5 establishes the conclusions.

\section{Six Phase Transmission Line and Data Generation}

The power system network is composed of a $138 \mathrm{kV}, 60$ $\mathrm{Hz}$ SPT line referring to the Springdale-McCalmont transmission line of $68 \mathrm{~km}$ length. The SPT line detailed parameters information is given in Appendix A. The MATLAB software is employed for SPT line model and multi location and transforming phase to ground faults simulation. The schematic diagram of SPT line for multi location and transforming phase to ground faults is depicted in figure. 1 .

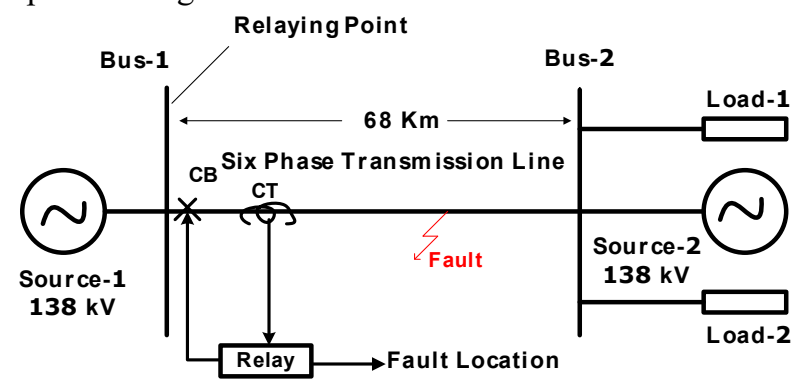

Fig. 1. Singleline diagram of SPT line

When a single phase to ground fault occurs in multi phases at the same time at different locations is called a multi location phase to ground fault. As shown in figure 2, multi location phase to ground fault condition i.e, Cphase to ground $(\mathrm{Cg})$ fault at $8 \mathrm{~km}$ and $\mathrm{D}$-phase to ground $(\mathrm{Dg})$ fault at $45 \mathrm{~km}$ with resistance $(\mathrm{Rf})=0 \Omega$ and time $=40 \mathrm{~ms}$ are considered. As depicted in figure 2, fault current in D-phase is less than C-phase because fault current decreases with increase in fault location from sending end. When line to ground fault transforms to double line to ground fault after sometime interval at the same location is called a transforming phase to ground fault. Figure 3, explains transforming phase to ground fault that initially $\mathrm{Cg}$ fault at $8 \mathrm{~km}$ in $40 \mathrm{~ms}$ time is transformed after $10 \mathrm{~ms}$ to $\mathrm{CDg}$ fault at the same location. As illustrated in figure 3, fault current is same 
in $\mathrm{C}$ and $\mathrm{D}$ phases but fault occurring times are different. The recorded instantaneous six phase currents are fed to a $2^{\text {nd }}$ low pass-butterworth filter (LP-BWF). The LP-BWF cut-off frequency is $480 \mathrm{~Hz}$. After that, these currents are sampled with sampling frequency of
$1.2 \mathrm{kHz}$. Then, signals are employed to one full cycle discrete fourier transform (DFT) for estimation of the fundamental components of six-phase current. Now these currents are normalized in between -1 to +1 .

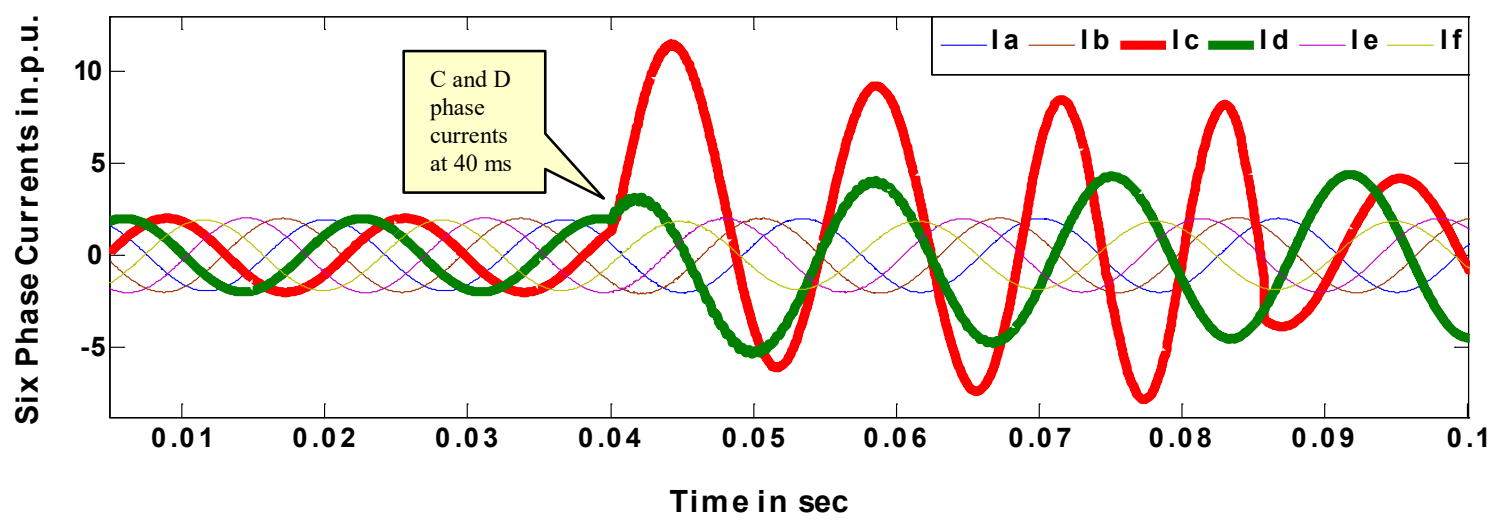

Fig. 2. Six phase currents during multi location phase to ground fault

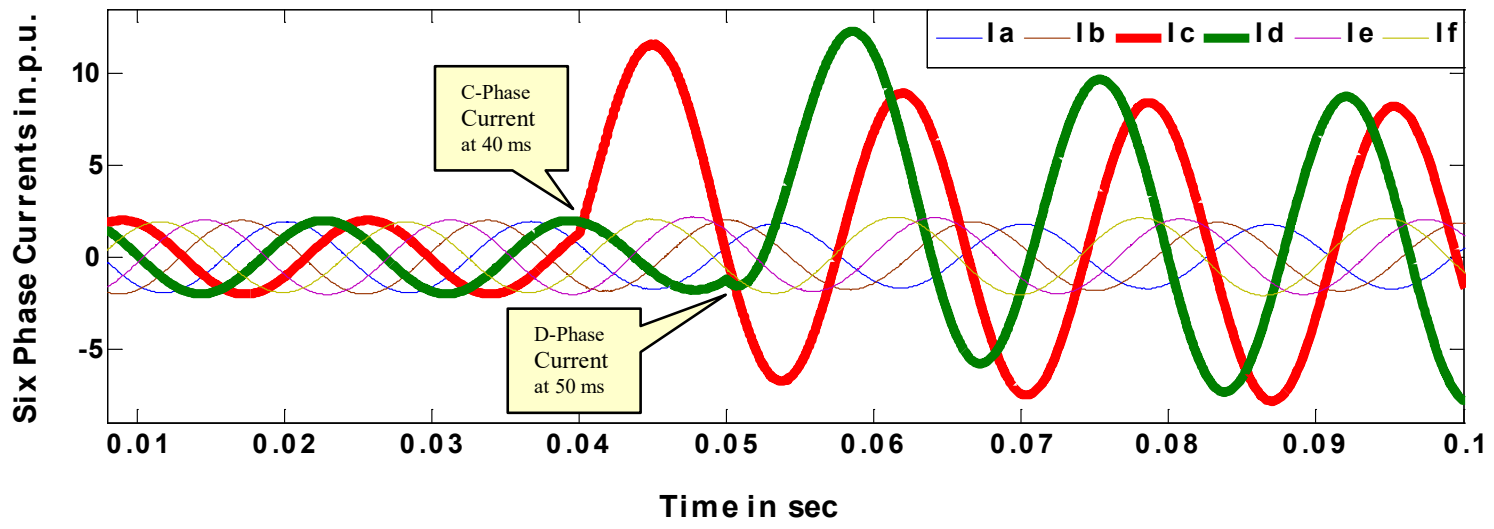

Fig. 3. Six phase currents during transforming phase to ground fault

\section{Procedure}

FIS is employed for the proposed fault location method. FIS provides a nonlinear input and output mapping technique. It is an ideal platform for handling different problems with noisy and incomplete information. Fuzzy logic system contains four components: fuzzification, rule base, fuzzy inference engine and defuzzification. The rule base consists of rules which are extracted from expert knowledge to express nonlinear relationship between input domain and output domain. The rules are generally represented as IF-THEN statements. After that, the aggregation process which combines the output of each IF-THEN rule into only one fuzzy set. Then the outputs of aggregation are defuzzified into crisp values using the centroid method. The architecture of FIS is shown in figure 4. Designing of FIS consists of three major steps.

Step-1.Decide the number of inputs and outputs.

Step-2.Designing their membership functions (MFs) Step-3.Implementing rules to connect inputs and outputs.

The framework of proposed FIS based location scheme for multi location and transforming phase to ground fault is illustrated in figure 5. The proposed fuzzy system is multi input-multi output system. Six inputs and six outputs are considered for FIS. The fundamental component of currents is fed into the FIS. Fault location 
in each phase is used as output. In this inputs represent $\mathrm{I}_{\mathrm{A}}, \mathrm{I}_{\mathrm{B}}, \mathrm{I}_{\mathrm{C}}, \mathrm{I}_{\mathrm{D}}, \mathrm{I}_{\mathrm{E}}$ and $\mathrm{I}_{\mathrm{F}}$. The outputs represent La, Lb, Lc, $\mathrm{Ld}$, Le and Lf. Mamdani FIS is applied to make decision. The non fuzzy values of inputs are converted into fuzzy degrees between 0 and 1 using triangular MFs. Each input has been separated into 3 partitions, viz. M1, M2 and M3 based on the location as depicted in figure 6. Similarly three groups of triangular MFs viz. DL1, DL2 and DL3 are designed for each output as illustrated in figure 7.In this $\mathrm{M} 1<\mathrm{M} 2<\mathrm{M} 3$ and DL $1<$ DL2 $<$ DL3. After constructing input output fuzzy sets, IF-THEN fuzzy rules are formulated to evaluate the location of multi location and transforming phase to ground faults. FIS composed of total 729 rules. Some samples of IF-THEN rules are shown below.

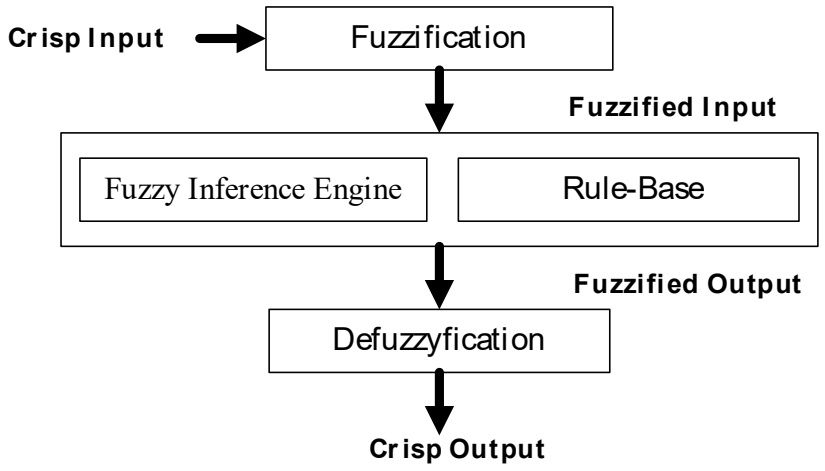

Fig. 4. Outline of FIS architecture

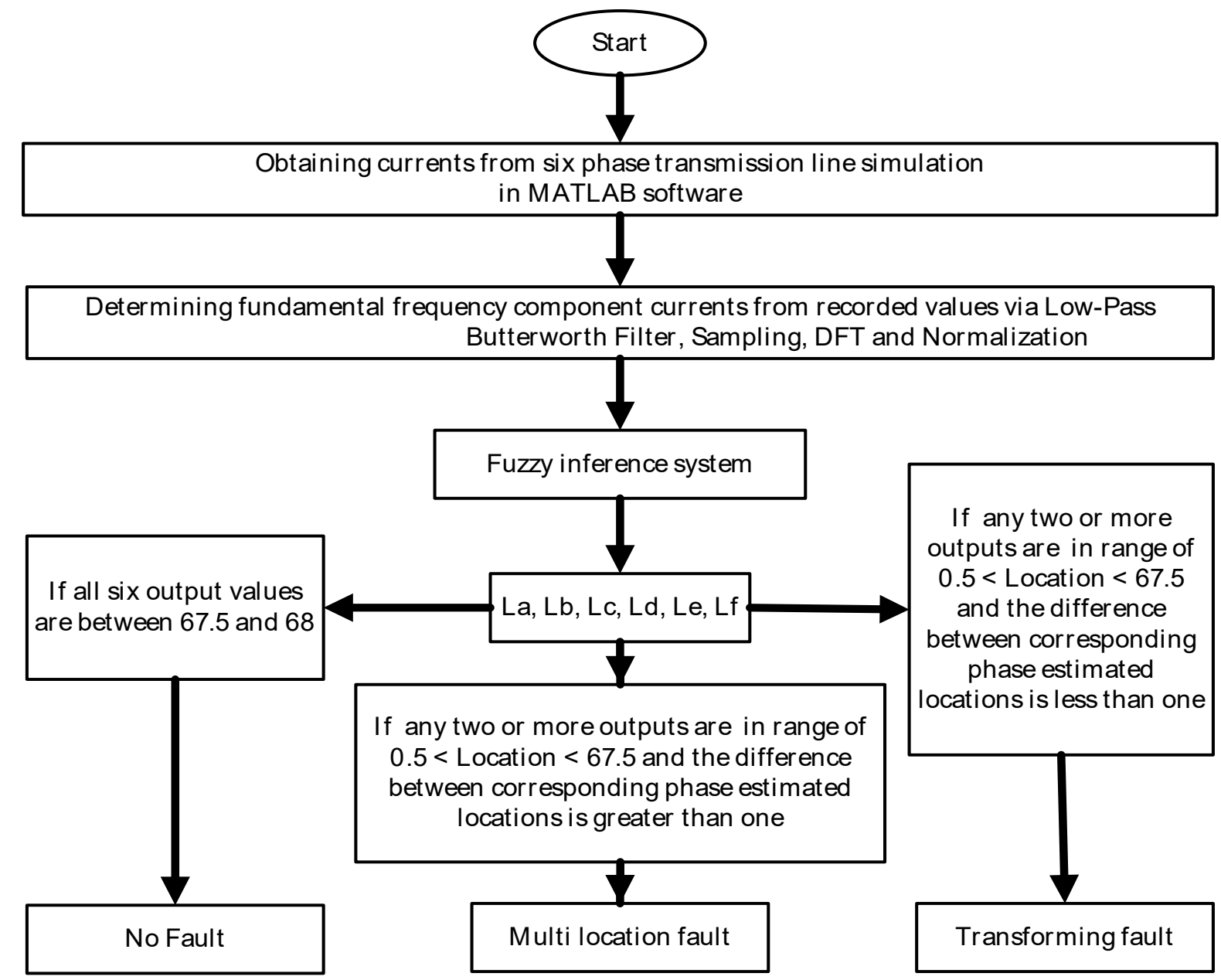

Fig. 5. Flow diagram of proposed work

\section{IF-THEN Rules}

Rule1: IF ( $I_{A}$ is M1) and ( $I_{B}$ is M1) and ( $I_{C}$ is M1) and ( $I_{D}$ is M1) and ( $I_{E}$ is M1) and ( $I_{F}$ is M1) 
THEN (La is DL3) (Lb is DL3) (Lc is DL3) (Ld is DL3) (Le is DL3) (Lf is DL3)

Rule2: IF ( $I_{A}$ is M1) and ( $I_{B}$ is M1) and ( $I_{C}$ is M1) and ( $I_{D}$ is M1) and ( $I_{E}$ is M1) and ( $I_{F}$ is M2)

THEN (La is DL3) (Lb is DL3) (Lc is DL3) (Ld is DL3) (Le is DL3) (Lf is DL2)

Rule3: IF ( $I_{A}$ is M1) and ( $I_{B}$ is M1) and ( $I_{C}$ is M1) and ( $I_{D}$ is M1) and ( $I_{E}$ is M1) and ( $I_{F}$ is M3)

THEN (La is DL3) (Lb is DL3) (Lc is DL3) (Ld is DL3) (Le is DL3) (Lf is DL1)

Rule4: IF ( $\mathrm{I}_{\mathrm{A}}$ is M1) and ( $\mathrm{I}_{\mathrm{B}}$ is M1) and ( $\mathrm{I}_{\mathrm{C}}$ is M1) and ( $\mathrm{I}_{\mathrm{D}}$ is M1) and ( $\mathrm{I}_{\mathrm{E}}$ is M2) and ( $\mathrm{I}_{\mathrm{F}}$ is M1)

THEN (La is DL3) (Lb is DL3) (Lc is DL3) (Ld is DL3) (Le is DL2) (Lf is DL3)

Rule5: IF ( $I_{A}$ is M1) and ( $I_{B}$ is M1) and ( $I_{C}$ is M1) and ( $I_{D}$ is M1) and ( $I_{E}$ is M2) and ( $I_{F}$ is M2)

THEN (La is DL3) (Lb is DL3) (Lc is DL3) (Ld is DL3) (Le is DL2) (Lf is DL2)

Rule6: IF ( $I_{A}$ is M1) and ( $I_{B}$ is M1) and ( $I_{C}$ is M1) and ( $I_{D}$ is M1) and ( $I_{E}$ is M2) and ( $I_{F}$ is M3) THEN (La is DL3) (Lb is DL3) (Lc is DL3) (Ld is DL3) (Le is DL2) (Lf is DL1)

Rule7: IF ( $I_{A}$ is M1) and ( $I_{B}$ is M1) and ( $I_{C}$ is M1) and ( $I_{D}$ is M1) and ( $I_{E}$ is M3) and ( $I_{F}$ is M1) THEN (La is DL3) (Lb is DL3) (Lc is DL3) (Ld is DL3) (Le is DL1) (Lf is DL3)

Rule8: IF ( $I_{A}$ is M1) and ( $I_{B}$ is M1) and ( $I_{C}$ is M1) and ( $I_{D}$ is M1) and ( $I_{E}$ is M3) and ( $I_{F}$ is M2) THEN (La is DL3) (Lb is DL3) (Lc is DL3) (Ld is DL3) (Le is DL1) (Lf is DL2)

Rule9: IF ( $I_{A}$ is M1) and ( $I_{B}$ is M1) and ( $I_{C}$ is M1) and ( $I_{D}$ is M1) and ( $I_{E}$ is M3) and ( $I_{F}$ is M3) THEN ( $\mathrm{La}$ is DL3) (Lb is DL3) (Lc is DL3) (Ld is DL3) (Le is DL1) (Lf is DL1)

Rule10: IF ( $I_{A}$ is M1) and ( $I_{B}$ is M1) and ( $I_{C}$ is M1) and ( $I_{D}$ is M2) and ( $I_{E}$ is M1) and ( $I_{F}$ is M1) THEN (La is DL3) (Lb is DL3) (Lc is DL3) (Ld is DL2) (Le is DL3) (Lf is DL3)

Rule27: IF ( $\mathrm{I}_{\mathrm{A}}$ is M1) and ( $\mathrm{I}_{\mathrm{B}}$ is M1) and ( $\mathrm{I}_{\mathrm{C}}$ is M1) and ( $\mathrm{I}_{\mathrm{D}}$ is M3) and ( $\mathrm{I}_{\mathrm{E}}$ is M3) and ( $\mathrm{I}_{F}$ is M3) THEN (La is DL3) (Lb is DL3) (Lc is DL3) (Ld is DL1) (Le is DL1) (Lf is DL1)

Rule28: IF ( $\mathrm{I}_{\mathrm{A}}$ is M1) and ( $\mathrm{I}_{\mathrm{B}}$ is M1) and ( $\mathrm{I}_{\mathrm{C}}$ is M2) and ( $\mathrm{I}_{\mathrm{D}}$ is M1) and ( $\mathrm{I}_{\mathrm{E}}$ is M1) and $\left(\mathrm{I}_{\mathrm{F}}\right.$ is M1) THEN (La is DL3) (Lb is DL3) (Lc is DL2) (Ld is DL3) (Le is DL3) (Lf is DL3)

Rule81: IF ( $I_{A}$ is M1) and ( $I_{B}$ is M1) and $\left(I_{C}\right.$ is M3) and ( $I_{D}$ is M3) and $\left(I_{E}\right.$ is M3) and ( $I_{F}$ is M3) THEN (La is DL3) (Lb is DL3) (Lc is DL1) (Ld is DL1) (Le is DL1) (Lf is DL1)

Rule82: IF ( $\mathrm{I}_{\mathrm{A}}$ is M1) and $\left(\mathrm{I}_{\mathrm{B}}\right.$ is M2) and $\left(\mathrm{I}_{\mathrm{C}}\right.$ is M1) and $\left(\mathrm{I}_{\mathrm{D}}\right.$ is M1) and ( $\mathrm{I}_{\mathrm{E}}$ is M1) and ( $\mathrm{I}_{\mathrm{F}}$ is M1) THEN (La is DL3) (Lb is DL2) (Lc is DL3) (Ld is DL3) (Le is DL3) (Lf is DL3)

Rule243: IF ( $\mathrm{I}_{\mathrm{A}}$ is M1) and ( $\mathrm{I}_{\mathrm{B}}$ is M3) and ( $\mathrm{I}_{\mathrm{C}}$ is M3) and ( $\mathrm{I}_{\mathrm{D}}$ is M3) and ( $\mathrm{I}_{\mathrm{E}}$ is M3) and ( $\mathrm{I}_{\mathrm{F}}$ is M3) THEN (La is DL3) (Lb is DL1) (Lc is DL1) (Ld is DL1) (Le is DL1) (Lf is DL1)

Rule244: IF ( $\mathrm{I}_{\mathrm{A}}$ is M2) and ( $\mathrm{I}_{\mathrm{B}}$ is M1) and ( $\mathrm{I}_{\mathrm{C}}$ is M1) and ( $\mathrm{I}_{\mathrm{D}}$ is M1) and ( $\mathrm{I}_{\mathrm{E}}$ is M1) and ( $\mathrm{I}_{\mathrm{F}}$ is M1) THEN (La is DL2) (Lb is DL3) (Lc is DL3) (Ld is DL3) (Le is DL3) (Lf is DL3)

Rule729: IF ( $\mathrm{I}_{A}$ is M3) and ( $\mathrm{I}_{\mathrm{B}}$ is M3) and ( $\mathrm{I}_{C}$ is M3) and $\left(\mathrm{I}_{\mathrm{D}}\right.$ is M3) and ( $\mathrm{I}_{\mathrm{E}}$ is M3) and $\left(\mathrm{I}_{\mathrm{F}}\right.$ is M3) THEN (La is DL1) (Lb is DL1) (Lc is DL1) (Ld is DL1) (Le is DL1) (Lf is DL1) 


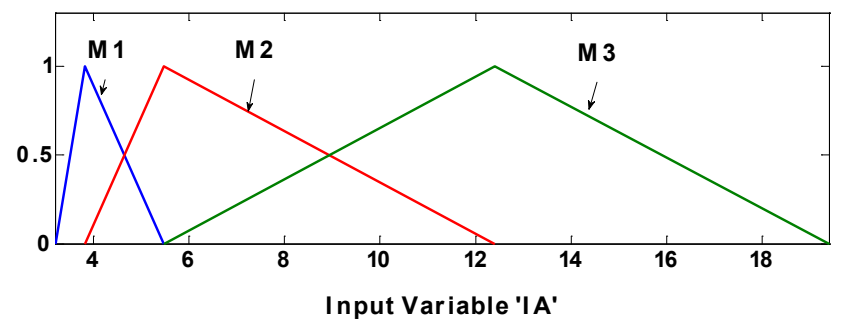

Fig. 6. Degree of MF for input of FIS

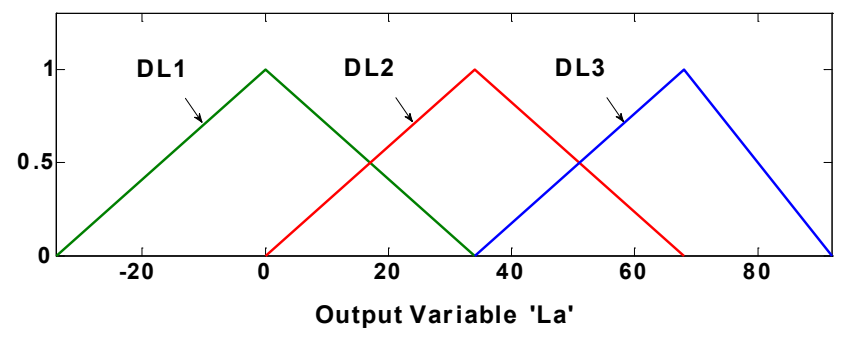

Fig. 7. Degree of MF for output of FIS

After it combine the obtained outputs for each rule into a fuzzy set with a maximum fuzzy aggregation operator. The fuzzy set is then transformed into a numerical value by aggregating the consequents using centroid method to produce a non fuzzy value within 0 and 68. Now FIS is able to take the input currents and ready to locate multi location and transforming phase to ground faults.

\section{Performance Evaluation}

\subsection{Multi location phase to ground faults}

The proposed method is validated using data obtained from the MATLAB software. During healthy operating condition, all the six outputs are set to give the location value $67.5<$ Location $<68 \mathrm{~km}$. When the SPT line is subjected to multi location phase to ground fault at different locations in different phases then the outputs of corresponding faulty phases will give the different fault location values are in range of $0.5<$ Location $<68$ and healthy phase will be $68 \mathrm{~km}$. The six outputs $\mathrm{La}, \mathrm{Lb}, \mathrm{Lc}$, $\mathrm{Ld}$, Le and $\mathrm{Lf}$ of the proposed method determine whether the fault is single location transforming phase to ground fault or multi location phase to ground fault. If any of the six outputs are in range of $0.5<$ Location $<$ 67.5 and the difference between corresponding phase estimated locations is greater than one then it is multilocation phase to ground fault. If any of the six outputs are in range of $0.5<$ Location $<67.5$ and the difference between corresponding phase estimated locations is less than one. Then the fault is treated as single location transforming phase to ground fault.

Most of phase to ground faults occurs without or with Rf. Majority of the fault location techniques are influenced by the Rf. Some of location techniques are not reliable due to the result of DC offset for variation in fault inception values. Therefore, it is important to study the performance of proposed technique for different fault inception values. In ordered to test the feasibility of the proposed mode, a large number of the multi location phase to ground fault studies corresponding wide variation of fault resistance $(\mathrm{Rf}=35,70$ and $105 \Omega)$ and fault inception angle $\left(\Phi=45,90\right.$ and $\left.135^{\circ}\right)$. Table 1 presents the performance results of two location phase to ground faults for the different fault resistance and inception angles. Table 2 presents the performance results of three location phase to ground faults for the different fault resistance and inception angles. Table 3 presents the performance results of four location phase to ground faults for the different fault resistance and inception angles. Table 4 presents the performance results of five location phase to ground faults for the different fault resistance and inception angles. Table 5 presents the performance results of six location phase to ground faults for the different fault resistance and inception angles.

One sample of result for multi location phase to ground faults in MATLAB fuzzy software is given in figure 8. This result was obtained when $\mathrm{C}$-phase to ground $(\mathrm{Cg})$ fault at $20 \mathrm{~km}$ and E-phase to ground $(\mathrm{Eg})$ fault at $40 \mathrm{~km}$ with $\mathrm{Rf}=0 \Omega$ and time $=40 \mathrm{~ms}$ are considered. It can be observed here that faults are classified with the help of location results without classification technique. It also classifies and locates all types of phase to ground faults. Figure 9, illustrates the outputs of fault classification FIS in which ' $\mathrm{C}$ ' phase goes $20 \mathrm{~km}$ at $40 \mathrm{~ms}$ and $\mathrm{E}$ goes $40 \mathrm{~km}$ at $40 \mathrm{~ms}$, with other outputs $\mathrm{A}, \mathrm{B}, \mathrm{D}$ and $\mathrm{F}$ remaining high $(68 \mathrm{~km})$ showing there is CEg-multi location phase to ground fault. 
Table 1. Test results of FIS for two different location phase to ground faults.

\begin{tabular}{|c|c|c|c|c|c|c|c|}
\hline \multicolumn{2}{|c|}{ Parameter } & \multicolumn{3}{|c|}{$\operatorname{Rf}(\Omega)$} & \multicolumn{3}{|c|}{$\Phi\left(^{\circ}\right)$} \\
\hline Differen & & 35 & 70 & 105 & 45 & 90 & 135 \\
\hline \multicolumn{2}{|c|}{$\begin{array}{l}\text { Two different location } \\
\text { phase to ground faults }\end{array}$} & $\begin{array}{l}\mathrm{Ag} \text { at } 22 \mathrm{~km} \\
\mathrm{Bg} \text { at } 15 \mathrm{~km} \\
\text { with } \Phi=60^{\circ}\end{array}$ & $\begin{array}{l}\mathrm{Ag} \text { at } 18 \mathrm{~km} \\
\mathrm{Dg} \text { at } 13 \mathrm{~km} \\
\text { with } \Phi=60^{\circ}\end{array}$ & $\begin{array}{l}\text { Bg at } 62 \mathrm{~km} \\
\text { Dg at } 9 \mathrm{~km} \\
\text { with } \Phi=60^{\circ}\end{array}$ & $\begin{array}{l}\text { Eg at } 61 \mathrm{~km} \\
\text { Fg at } 41 \mathrm{~km} \\
\text { with } \mathrm{Rf}=0 \Omega\end{array}$ & $\begin{array}{l}\mathrm{Cg} \text { at } 33 \mathrm{~km} \\
\mathrm{Eg} \text { at } 6 \mathrm{~km} \\
\text { with } \mathrm{Rf}=0 \Omega\end{array}$ & $\begin{array}{l}\mathrm{Ag} \text { at } 55 \mathrm{~km} \\
\mathrm{Fg} \text { at } 17 \mathrm{~km} \\
\text { with } \mathrm{Rf}=0 \Omega\end{array}$ \\
\hline Phase A & $\mathrm{La}$ & 22.26 & 17.79 & 68 & 68 & 68 & 54.98 \\
\hline Phase B & $\mathrm{Lb}$ & 15.12 & 68 & 61.89 & 68 & 68 & 68 \\
\hline Phase C & $\mathrm{Lc}$ & 68 & 68 & 68 & 68 & 33.21 & 68 \\
\hline Phase D & $\mathrm{Ld}$ & 68 & 13.03 & 9.14 & 68 & 68 & 68 \\
\hline Phase E & $\mathrm{Le}$ & 68 & 68 & 68 & 61.17 & 5.85 & 68 \\
\hline Phase F & $\mathrm{Lf}$ & 68 & 68 & 68 & 40.97 & 68 & 17.01 \\
\hline
\end{tabular}

Table 2. Test results of FIS for three different location phase to ground faults.

\begin{tabular}{|c|c|c|c|c|c|c|c|}
\hline \multicolumn{2}{|c|}{ Parameter } & \multicolumn{3}{|c|}{$\operatorname{Rf}(\Omega)$} & \multicolumn{3}{|c|}{$\Phi\left(^{\circ}\right)$} \\
\hline Differen & & 35 & 70 & 105 & 45 & 90 & 135 \\
\hline \multicolumn{2}{|c|}{$\begin{array}{l}\text { Three different location } \\
\text { phase to ground faults }\end{array}$} & $\begin{array}{l}\mathrm{Ag} \text { at } 46 \mathrm{~km} \\
\mathrm{Cg} \text { at } 8 \mathrm{~km} \\
\text { Eg at } 33 \mathrm{~km} \\
\text { with } \Phi=60^{\circ}\end{array}$ & $\begin{array}{l}\mathrm{Cg} \text { at } 27 \mathrm{~km} \\
\mathrm{Dg} \text { at } 13 \mathrm{~km} \\
\text { Fg at } 66 \mathrm{~km} \\
\text { with } \Phi=60^{\circ}\end{array}$ & $\begin{array}{l}\text { Bg at } 3 \mathrm{~km} \\
\mathrm{Dg} \text { at } 43 \mathrm{~km} \\
\text { Eg at } 53 \mathrm{~km} \\
\text { with } \Phi=60^{\circ}\end{array}$ & $\begin{array}{l}\text { Dg at } 60 \mathrm{~km} \\
\text { Eg at } 5 \mathrm{~km} \\
\text { Fg at } 2 \mathrm{~km} \\
\text { with } \mathrm{Rf}=0 \Omega\end{array}$ & $\begin{array}{l}\mathrm{Ag} \text { at } 61 \mathrm{~km} \\
\mathrm{Bg} \text { at } 13 \mathrm{~km} \\
\mathrm{Cg} \text { at } 11 \mathrm{~km} \\
\text { with } \mathrm{Rf}=0 \Omega\end{array}$ & $\begin{array}{l}\mathrm{Bg} \text { at } 19 \mathrm{~km} \\
\mathrm{Eg} \text { at } 27 \mathrm{~km} \\
\mathrm{Fg} \text { at } 37 \mathrm{~km} \\
\text { with } \mathrm{Rf}=0 \Omega\end{array}$ \\
\hline Phase A & $\mathrm{La}$ & 46.13 & 68 & 68 & 68 & 61.19 & 68 \\
\hline Phase B & $\mathrm{Lb}$ & 68 & 68 & 2.71 & 68 & 12.82 & 19.01 \\
\hline Phase C & $\mathrm{Lc}$ & 7.92 & 27.08 & 68 & 68 & 11.00 & 68 \\
\hline Phase D & $\mathrm{Ld}$ & 68 & 12.90 & 43.13 & 59.83 & 68 & 68 \\
\hline Phase E & $\mathrm{Le}$ & 33.24 & 68 & 53.16 & 5.18 & 68 & 27.13 \\
\hline Phase F & Lf & 68 & 65.77 & 68 & 2.06 & 68 & 36.96 \\
\hline
\end{tabular}

Table 3. Test results of FIS for four different location phase to ground faults.

\begin{tabular}{|c|c|c|c|c|c|c|c|}
\hline \multicolumn{2}{|c|}{ Parameter } & \multicolumn{3}{|c|}{$\operatorname{Rf}(\Omega)$} & \multicolumn{3}{|c|}{$\Phi\left(^{\circ}\right)$} \\
\hline Differen & & 35 & 70 & 105 & 45 & 90 & 135 \\
\hline $\begin{array}{l}\text { Four dif } \\
\text { phase to }\end{array}$ & $\begin{array}{l}\text { location } \\
\text { nd faults }\end{array}$ & $\begin{array}{l}\text { Ag at } 5 \mathrm{~km} \\
\text { Dg at } 42 \mathrm{~km} \\
\text { Eg at } 31 \mathrm{~km} \\
\text { Fg at } 14 \mathrm{~km} \\
\text { with } \Phi=60^{\circ}\end{array}$ & $\begin{array}{l}\text { Bg at } 24 \mathrm{~km} \\
\mathrm{Dg} \text { at } 25 \mathrm{~km} \\
\mathrm{Eg} \text { at } 18 \mathrm{~km} \\
\mathrm{Fg} \text { at } 1 \mathrm{~km} \\
\text { with } \Phi=60^{\circ}\end{array}$ & $\begin{array}{l}\mathrm{Cg} \text { at } 11 \mathrm{~km} \\
\mathrm{Dg} \text { at } 35 \mathrm{~km} \\
\mathrm{Eg} \text { at } 44 \mathrm{~km} \\
\mathrm{Fg} \text { at } 15 \mathrm{~km} \\
\text { with } \Phi=60^{\circ}\end{array}$ & $\begin{array}{l}\mathrm{Bg} \text { at } 58 \mathrm{~km} \\
\mathrm{Cg} \text { at } 21 \mathrm{~km} \\
\mathrm{Dg} \text { at } 9 \mathrm{~km} \\
\mathrm{Eg} \text { at } 17 \mathrm{~km} \\
\text { with } \mathrm{Rf}=0 \Omega\end{array}$ & $\begin{array}{l}\mathrm{Ag} \text { at } 33 \mathrm{~km} \\
\mathrm{Bg} \text { at } 16 \mathrm{~km} \\
\mathrm{Cg} \text { at } 19 \mathrm{~km} \\
\mathrm{Dg} \text { at } 47 \mathrm{~km} \\
\text { with } \mathrm{Rf}=0 \Omega\end{array}$ & $\begin{array}{l}\mathrm{Ag} \text { at } 8 \mathrm{~km} \\
\mathrm{Bg} \text { at } 50 \mathrm{~km} \\
\mathrm{Cg} \text { at } 23 \mathrm{~km} \\
\mathrm{Fg} \text { at } 13 \mathrm{~km} \\
\text { with } \mathrm{Rf}=0 \Omega\end{array}$ \\
\hline Phase A & $\mathrm{La}$ & 4.91 & 68 & 68 & 68 & 32.78 & 7.76 \\
\hline Phase B & $\mathrm{Lb}$ & 68 & 24.11 & 68 & 58.04 & 16.16 & 49.89 \\
\hline Phase C & $\mathrm{Lc}$ & 68 & 68 & 10.94 & 20.98 & 19.27 & 23.13 \\
\hline Phase D & $\mathrm{Ld}$ & 42.32 & 25.24 & 35.16 & 9.14 & 46.72 & 68 \\
\hline Phase E & $\mathrm{Le}$ & 31.30 & 18.15 & 43.80 & 17.09 & 68 & 68 \\
\hline Phase F & Lf & 14.25 & 0.69 & 15.21 & 68 & 68 & 12.75 \\
\hline
\end{tabular}

Table 4.Test results of FIS for five different location phase to ground faults.

\begin{tabular}{|c|c|c|c|c|c|c|c|}
\hline \multicolumn{2}{|c|}{ Parameter } & \multicolumn{3}{|c|}{$\operatorname{Rf}(\Omega)$} & \multicolumn{3}{|c|}{$\Phi\left(^{\circ}\right)$} \\
\hline Differen & & 35 & 70 & 105 & 45 & 90 & 135 \\
\hline \multicolumn{2}{|c|}{$\begin{array}{l}\text { Five different location } \\
\text { phase to ground faults }\end{array}$} & $\begin{array}{l}\mathrm{Ag} \text { at } 16 \mathrm{~km} \\
\mathrm{Bg} \text { at } 10 \mathrm{~km} \\
\mathrm{Cg} \text { at } 61 \mathrm{~km} \\
\mathrm{Dg} \text { at } 15 \mathrm{~km} \\
\text { Eg at } 53 \mathrm{~km} \\
\text { with } \Phi=60^{\circ}\end{array}$ & $\begin{array}{l}\text { Ag at } 63 \mathrm{~km} \\
\mathrm{Bg} \text { at } 28 \mathrm{~km} \\
\mathrm{Cg} \text { at } 9 \mathrm{~km} \\
\mathrm{Dg} \text { at } 13 \mathrm{~km} \\
\mathrm{Fg} \text { at } 65 \mathrm{~km} \\
\text { with } \Phi=60^{\circ}\end{array}$ & $\begin{array}{l}\mathrm{Ag} \text { at } 25 \mathrm{~km} \\
\mathrm{Bg} \text { at } 34 \mathrm{~km} \\
\mathrm{Cg} \text { at } 51 \mathrm{~km} \\
\mathrm{Eg} \text { at } 30 \mathrm{~km} \\
\mathrm{Fg} \text { at } 7 \mathrm{~km} \\
\text { with } \Phi=60^{\circ}\end{array}$ & $\begin{array}{l}\text { Ag at } 35 \mathrm{~km} \\
\text { Bg at } 1 \mathrm{~km} \\
\text { Dg at } 43 \mathrm{~km} \\
\text { Eg at } 6 \mathrm{~km} \\
\text { Fg at } 56 \mathrm{~km} \\
\text { with } \mathrm{Rf}=0 \Omega\end{array}$ & $\begin{array}{l}\mathrm{Ag} \text { at } 9 \mathrm{~km} \\
\mathrm{Cg} \text { at } 13 \mathrm{~km} \\
\mathrm{Dg} \text { at } 40 \mathrm{~km} \\
\mathrm{Eg} \text { at } 24 \mathrm{~km} \\
\mathrm{Fg} \text { at } 32 \mathrm{~km} \\
\text { with } \mathrm{Rf}=0 \Omega\end{array}$ & $\begin{array}{l}\mathrm{Bg} \text { at } 36 \mathrm{~km} \\
\mathrm{Cg} \text { at } 48 \mathrm{~km} \\
\mathrm{Dg} \text { at } 21 \mathrm{~km} \\
\mathrm{Eg} \text { at } 26 \mathrm{~km} \\
\mathrm{Fg} \text { at } 11 \mathrm{~km} \\
\text { with } \mathrm{Rf}=0 \Omega\end{array}$ \\
\hline Phase A & $\mathrm{La}$ & 16.23 & 63.18 & 24.81 & 34.83 & 9.33 & 68 \\
\hline Phase B & $\mathrm{Lb}$ & 10.32 & 27.86 & 34.00 & 0.94 & 68 & 36.15 \\
\hline Phase C & $\mathrm{Lc}$ & 60.91 & 8.83 & 51.22 & 68 & 13.06 & 48.24 \\
\hline Phase D & $\mathrm{Ld}$ & 15.11 & 12.86 & 68 & 42.97 & 40.19 & 21.06 \\
\hline Phase E & Le & 52.97 & 68 & 30.16 & 5.74 & 23.85 & 25.96 \\
\hline Phase F & Lf & 68 & 64.70 & 7.27 & 56.05 & 32.23 & 11.05 \\
\hline
\end{tabular}


Table 5.Test results of FIS for six different location phase to ground faults.

\begin{tabular}{|c|c|c|c|c|c|c|c|}
\hline \multicolumn{2}{|c|}{ Parameter } & \multicolumn{3}{|c|}{$\operatorname{Rf}(\Omega)$} & \multicolumn{3}{|c|}{$\Phi\left(^{\circ}\right)$} \\
\hline Different & & 35 & 70 & 105 & 45 & 90 & 135 \\
\hline \multirow{6}{*}{\multicolumn{2}{|c|}{$\begin{array}{l}\text { Six different location } \\
\text { phase to ground faults }\end{array}$}} & $\mathrm{Ag}$ at $12 \mathrm{~km}$ & $\mathrm{Ag}$ at $63 \mathrm{~km}$ & $\mathrm{Ag}$ at $16 \mathrm{~km}$ & $\mathrm{Ag}$ at $18 \mathrm{~km}$ & $\mathrm{Ag}$ at $61 \mathrm{~km}$ & $\mathrm{Ag}$ at $48 \mathrm{~km}$ \\
\hline & & $\mathrm{Bg}$ at $6 \mathrm{~km}$ & $\mathrm{Bg}$ at $21 \mathrm{~km}$ & $\mathrm{Bg}$ at $15 \mathrm{~km}$ & $\mathrm{Bg}$ at $1 \mathrm{~km}$ & $\mathrm{Bg}$ at $12 \mathrm{~km}$ & $\mathrm{Bg}$ at $13 \mathrm{~km}$ \\
\hline & & $\mathrm{Cg}$ at $35 \mathrm{~km}$ & $\mathrm{Cg}$ at $39 \mathrm{~km}$ & $\mathrm{Cg}$ at $54 \mathrm{~km}$ & $\mathrm{Cg}$ at $26 \mathrm{~km}$ & $\mathrm{Cg}$ at $4 \mathrm{~km}$ & $\mathrm{Cg}$ at $52 \mathrm{~km}$ \\
\hline & & Dg at $21 \mathrm{~km}$ & Dg at $34 \mathrm{~km}$ & Dg at $31 \mathrm{~km}$ & Dg at $24 \mathrm{~km}$ & Dg at $55 \mathrm{~km}$ & Dg at $7 \mathrm{~km}$ \\
\hline & & $\mathrm{Eg}$ at $16 \mathrm{~km}$ & Eg at $51 \mathrm{~km}$ & Eg at $61 \mathrm{~km}$ & Eg at $65 \mathrm{~km}$ & Eg at $9 \mathrm{~km}$ & Eg at $14 \mathrm{~km}$ \\
\hline & & $\begin{array}{l}\text { Fg at } 13 \mathrm{~km} \\
\text { with } \Phi=60^{\circ}\end{array}$ & $\begin{array}{l}\text { Fg at } 67 \mathrm{~km} \\
\text { with } \Phi=60^{\circ}\end{array}$ & $\begin{array}{l}\text { Fg at } \quad 6 \mathrm{~km} \\
\text { with } \Phi=60^{\circ}\end{array}$ & $\begin{array}{l}\text { Fg at } 38 \mathrm{~km} \\
\text { with } \mathrm{Rf}=0 \Omega\end{array}$ & $\begin{array}{l}\text { Fg at } 37 \mathrm{~km} \\
\text { with } \mathrm{Rf}=0 \Omega\end{array}$ & $\begin{array}{l}\text { Fg at } 19 \mathrm{~km} \\
\text { with } \mathrm{Rf}=0 \Omega\end{array}$ \\
\hline Phase A & $\mathrm{La}$ & 12.03 & 63.11 & 15.74 & 18.16 & 61.24 & 48.14 \\
\hline Phase B & $\mathrm{Lb}$ & 6.29 & 21.30 & 15.11 & 1.25 & 12.23 & 13.10 \\
\hline Phase C & $\mathrm{Lc}$ & 34.96 & 39.22 & 54.03 & 26.12 & 4.31 & 52.29 \\
\hline Phase D & $\mathrm{Ld}$ & 21.19 & 34.21 & 31.18 & 23.86 & 55.3 & 7.13 \\
\hline Phase E & Le & 15.87 & 51.02 & 61.11 & 65.23 & 8.85 & 13.84 \\
\hline Phase F & Lf & 13.22 & 67.10 & 6.21 & 38.06 & 36.98 & 19.12 \\
\hline
\end{tabular}

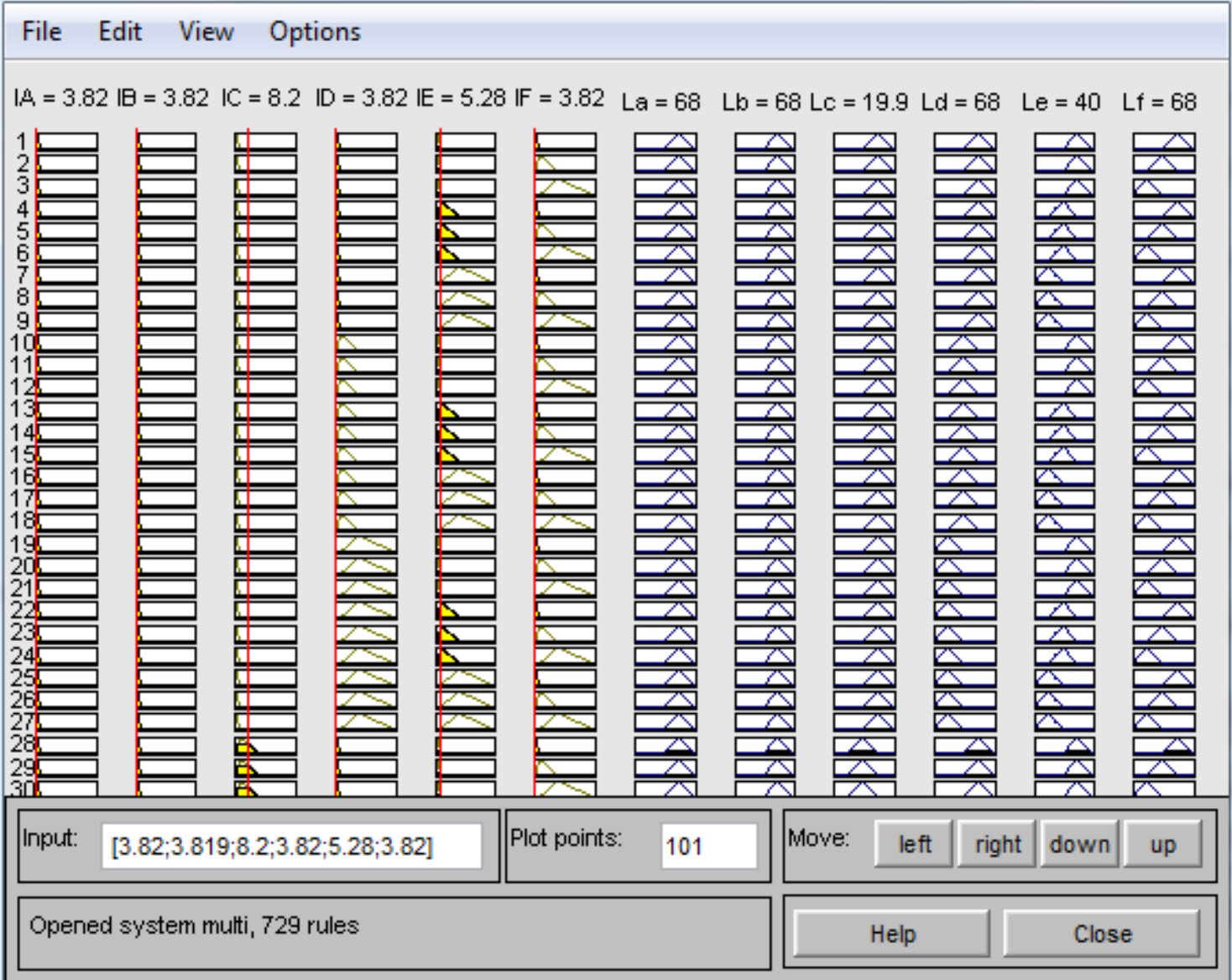

Fig. 8. Evaluation view of FIS output in case of multi location faults 


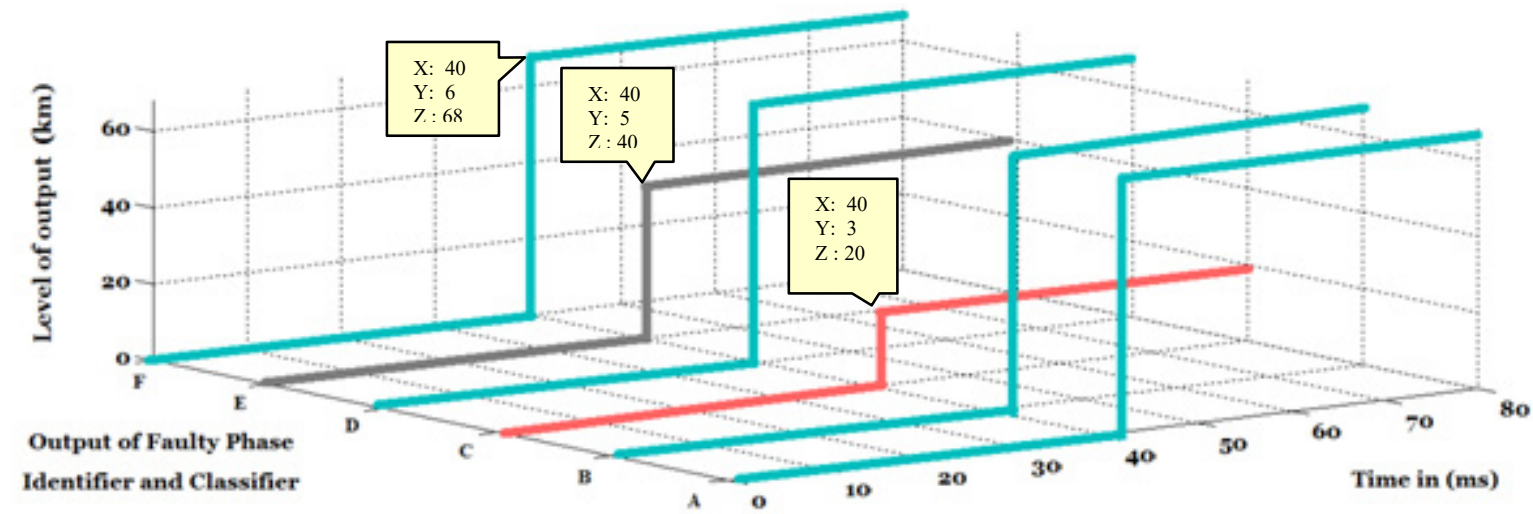

Fig. 9. Classification view of FIS output in case of multi location faults

\subsection{Transforming phase to ground faults}

In addition to multi location phase to ground faults, transforming phase to ground faults also occur in SPT line. When the SPT line is subjected to transforming phase to ground fault at same location in different phases then the output of corresponding faulty phases will give the same fault location values are in range of $0.5<$ Location $<68$ and healthy phase will be $68 \mathrm{~km}$. The proposed system is able to locate not only multi location phase to ground faults, but also transforming phase to ground faults. The proposed FIS method has been evaluated for around 1000 fault simulation cases and has been carried out under transforming faults with varying parameters such as fault location, fault resistance and fault inception angle. The performance results obtained by the proposed method for transforming faults based on fuzzy are summarized in table 6-10.

One sample of result for transforming phase to ground faults in MATLAB fuzzy software is given in figure 10 . Figure 11, depicts the outputs of fault classification FIS in which 'D' phase goes $20 \mathrm{~km}$ at $40 \mathrm{~ms}$ and $\mathrm{E}$ goes 20 $\mathrm{km}$ at $50 \mathrm{~ms}$, with other outputs $\mathrm{A}, \mathrm{B}, \mathrm{C}$ and $\mathrm{F}$ remaining high $(68 \mathrm{~km})$ showing there is DEg-transforming phase to ground fault. It can be found that most of the test cases can be located with $0.34 \mathrm{~km}$ difference.

Table 6. Test results of FIS for single phase to ground fault transformed to other phase to ground faults.

\begin{tabular}{|c|c|c|c|c|c|c|c|}
\hline \multirow{2}{*}{\multicolumn{2}{|c|}{$\begin{array}{l}\text { Parameter } \\
\text { Different values } \\
\end{array}$}} & \multicolumn{3}{|c|}{$\operatorname{Rf}(\Omega)$} & \multicolumn{3}{|c|}{$\Phi\left(^{\circ}\right)$} \\
\hline & & 35 & 70 & 105 & 45 & 90 & 135 \\
\hline \multicolumn{2}{|c|}{$\begin{array}{l}1 \text { phase to ground transformed } \\
\text { to other phases }\end{array}$} & $\begin{array}{l}\text { Eg to } \\
\text { EFg } \\
\text { at } 8 \mathrm{~km} \\
\text { with } \Phi=60^{\circ}\end{array}$ & $\begin{array}{l}\text { Cg to } \\
\text { CDEg } \\
\text { at } 17 \mathrm{~km} \\
\text { with } \Phi=60^{\circ}\end{array}$ & $\begin{array}{l}\text { Ag to } \\
\text { ABCDg } \\
\text { at } 54 \mathrm{~km} \\
\text { with } \Phi=60^{\circ}\end{array}$ & $\begin{array}{l}\text { Bg to } \\
\text { BCg } \\
\text { at } 66 \mathrm{~km} \\
\text { with } \mathrm{Rf}=0 \Omega\end{array}$ & $\begin{array}{l}\text { Ag to } \\
\mathrm{ABCDEg} \\
\text { at } 22 \mathrm{~km} \\
\text { with } \mathrm{Rf}=0 \Omega\end{array}$ & $\begin{array}{l}\text { Ag to } \\
\text { ABCDEFg } \\
\text { at } 12 \mathrm{~km} \\
\text { with } \mathrm{Rf}=0 \Omega\end{array}$ \\
\hline Phase A & $\mathrm{La}$ & 68 & 68 & 54.34 & 68 & 22.01 & 12.03 \\
\hline Phase B & $\mathrm{Lb}$ & 68 & 68 & 53.99 & 65.88 & 21.93 & 12.12 \\
\hline Phase C & Lc & 68 & 17.32 & 54.16 & 65.80 & 22.03 & 12.05 \\
\hline Phase D & $\mathrm{Ld}$ & 68 & 17.05 & 54.06 & 68 & 22.06 & 12.05 \\
\hline Phase E & Le & 8.02 & 16.86 & 68 & 68 & 22.10 & 12.09 \\
\hline Phase F & Lf & 8.09 & 68 & 68 & 68 & 68 & 12.00 \\
\hline
\end{tabular}

Table 7. Test results of FIS for two phase to ground fault transformed to other phase to ground faults.

\begin{tabular}{|c|c|c|c|c|c|c|c|}
\hline \multirow{2}{*}{\multicolumn{2}{|c|}{ Parameter }} & \multicolumn{3}{|c|}{$\operatorname{Rf}(\Omega)$} & \multicolumn{3}{|c|}{$\Phi\left(^{\circ}\right)$} \\
\hline & & 35 & 70 & 105 & 45 & 90 & 135 \\
\hline \multicolumn{2}{|c|}{$\begin{array}{l}2 \text { phase to ground transformed } \\
\text { to other phases }\end{array}$} & $\begin{array}{l}\text { BCg to } \\
\text { BCDg } \\
\text { at } 29 \mathrm{~km} \\
\text { with } \Phi=60^{\circ}\end{array}$ & $\begin{array}{l}\text { CDg to } \\
\text { CDEFg } \\
\text { at } 18 \mathrm{~km} \\
\text { with } \Phi=60^{\circ}\end{array}$ & $\begin{array}{l}\text { ABg to } \\
\text { ABCDEg } \\
\text { at } 32 \mathrm{~km} \\
\text { with } \Phi=60^{\circ}\end{array}$ & $\begin{array}{l}\text { DEg to } \\
\text { DEFg } \\
\text { at } 24 \mathrm{~km} \\
\text { with } \mathrm{Rf}=0 \Omega\end{array}$ & $\begin{array}{l}\text { ABg to } \\
\text { ABCDFg } \\
\text { at } 67 \mathrm{~km} \\
\text { with } \mathrm{Rf}=0 \Omega\end{array}$ & $\begin{array}{l}\mathrm{ABg} \text { to } \\
\mathrm{ABCDEFg} \\
\text { at } 48 \mathrm{~km} \\
\text { with } \mathrm{Rf}=0 \Omega\end{array}$ \\
\hline Phase A & $\mathrm{La}$ & 68 & 68 & 31.93 & 68 & 67.23 & 48.02 \\
\hline Phase B & $\mathrm{Lb}$ & 29.19 & 68 & 32.00 & 68 & 67.31 & 48.25 \\
\hline Phase C & $\mathrm{Lc}$ & 29.23 & 18.03 & 32.06 & 68 & 67.04 & 48.12 \\
\hline Phase D & $\mathrm{Ld}$ & 28.85 & 17.85 & 31.87 & 23.79 & 66.85 & 48.08 \\
\hline Phase E & Le & 68 & 17.98 & 31.99 & 24.08 & 68 & 48.03 \\
\hline Phase F & Lf & 68 & 17.96 & 68 & 24.17 & 66.83 & 47.76 \\
\hline
\end{tabular}


Table 8. Test results of FIS for three phase to ground fault transformed to other phase to ground faults.

\begin{tabular}{|c|c|c|c|c|c|c|c|}
\hline \multicolumn{2}{|c|}{ Parameter } & \multicolumn{3}{|c|}{$\operatorname{Rf}(\Omega)$} & \multicolumn{3}{|c|}{$\Phi\left(^{\circ}\right)$} \\
\hline Different & & 35 & 70 & 105 & 45 & 90 & 135 \\
\hline \multicolumn{2}{|c|}{$\begin{array}{l}3 \text { phase to ground transformed } \\
\text { to other phases }\end{array}$} & $\begin{array}{l}\text { ABCg to } \\
\text { ABCDg } \\
\text { at } 14 \mathrm{~km} \\
\text { with } \Phi=60^{\circ}\end{array}$ & $\begin{array}{l}\text { ABCg to } \\
\text { ABCDEg } \\
\text { at } 11 \mathrm{~km} \\
\text { with } \Phi=60^{\circ}\end{array}$ & $\begin{array}{l}\mathrm{ABCg} \text { to } \\
\mathrm{ABCDEFg} \\
\text { at } 36 \mathrm{~km} \\
\text { with } \Phi=60^{\circ}\end{array}$ & $\begin{array}{l}\mathrm{ABCg} \text { to } \\
\mathrm{ABCDg} \\
\text { at } 21 \mathrm{~km} \\
\text { with } \mathrm{Rf}=0 \Omega\end{array}$ & $\begin{array}{l}\mathrm{ABCg} \text { to } \\
\mathrm{ABCDEg} \\
\text { at } 24 \mathrm{~km} \\
\text { with } \mathrm{Rf}=0 \Omega\end{array}$ & $\begin{array}{l}\text { ABCg to } \\
\mathrm{ABCDEFg} \\
\text { at } 38 \mathrm{~km} \\
\text { with } \mathrm{Rf}=0 \Omega\end{array}$ \\
\hline Phase A & $\mathrm{La}$ & 13.89 & 10.97 & 36.22 & 21.03 & 24.05 & 38.09 \\
\hline Phase B & $\mathrm{Lb}$ & 13.80 & 11.04 & 35.99 & 20.95 & 24.13 & 38.15 \\
\hline Phase C & $\mathrm{Lc}$ & 14.21 & 11.05 & 36.21 & 21.24 & 24.32 & 38.23 \\
\hline Phase D & $\mathrm{Ld}$ & 14.05 & 11.23 & 36.02 & 21.08 & 24.31 & 37.98 \\
\hline Phase E & $\mathrm{Le}$ & 68 & 10.88 & 36.03 & 68 & 24.06 & 37.77 \\
\hline Phase F & Lf & 68 & 68 & 36.08 & 68 & 68 & 38.08 \\
\hline
\end{tabular}

Table 9. Test results of FIS for four phase to ground fault transformed to other phase to ground faults.

\begin{tabular}{|c|c|c|c|c|c|c|c|}
\hline \multirow{2}{*}{\multicolumn{2}{|c|}{$\begin{array}{l}\text { Parameter } \\
\text { Different values }\end{array}$}} & \multicolumn{3}{|c|}{$\operatorname{Rf}(\Omega)$} & \multicolumn{3}{|c|}{$\Phi\left(^{\circ}\right)$} \\
\hline & & 35 & 70 & 105 & 45 & 90 & 135 \\
\hline \multicolumn{2}{|c|}{$\begin{array}{l}4 \text { phase to ground transformed } \\
\text { to other phases }\end{array}$} & $\begin{array}{l}\text { ABCDg to } \\
\text { ABCDEg } \\
\text { at } 21 \mathrm{~km} \\
\text { with } \Phi=60^{\circ}\end{array}$ & $\begin{array}{l}\text { ABCDg to } \\
\text { ABCDEg } \\
\text { at } 58 \mathrm{~km} \\
\text { with } \Phi=60^{\circ}\end{array}$ & $\begin{array}{l}\text { ABCDg to } \\
\text { ABCDEg } \\
\text { at } 52 \mathrm{~km} \\
\text { with } \Phi=60^{\circ}\end{array}$ & $\begin{array}{l}\text { ABCDg to } \\
\text { ABCDFg } \\
\text { at } 16 \mathrm{~km} \\
\text { with } \mathrm{Rf}=0 \Omega\end{array}$ & $\begin{array}{l}\text { ABCDg to } \\
\text { ABCDFg } \\
\text { at } 31 \mathrm{~km} \\
\text { with } \mathrm{Rf}=0 \Omega\end{array}$ & $\begin{array}{l}\text { ABCDg to } \\
\text { ABCDFg } \\
\text { at } 15 \mathrm{~km} \\
\text { with } \mathrm{Rf}=0 \Omega\end{array}$ \\
\hline Phase A & $\mathrm{La}$ & 21.13 & 58.21 & 51.75 & 16.25 & 31.02 & 15.11 \\
\hline Phase B & $\mathrm{Lb}$ & 21.07 & 58.19 & 51.69 & 16.33 & 31.24 & 15.06 \\
\hline Phase C & $\mathrm{Lc}$ & 21.33 & 58.22 & 52.02 & 16.33 & 31.34 & 14.96 \\
\hline Phase D & $\mathrm{Ld}$ & 21.21 & 58.15 & 52.20 & 16.15 & 31.20 & 15.32 \\
\hline Phase E & $\mathrm{Le}$ & 21.33 & 58.21 & 52.10 & 68 & 68 & 68 \\
\hline Phase F & Lf & 68 & 68 & 68 & 16.04 & 31.07 & 15.16 \\
\hline
\end{tabular}

Table 10. Test results of FIS for five phase to ground fault transformed to other phase to ground faults.

\begin{tabular}{|c|c|c|c|c|c|c|c|}
\hline \multicolumn{2}{|c|}{ Parameter } & \multicolumn{3}{|c|}{$\operatorname{Rf}(\Omega)$} & \multicolumn{3}{|c|}{$\Phi\left(^{\circ}\right)$} \\
\hline Different & & 35 & 70 & 105 & 45 & 90 & 135 \\
\hline \multicolumn{2}{|c|}{$\begin{array}{l}5 \text { phase to ground transformed } \\
\text { to other phases }\end{array}$} & $\begin{array}{l}\text { ABCDEg to } \\
\text { ABCDEFg } \\
\text { at } 63 \mathrm{~km} \\
\text { with } \Phi=60^{\circ}\end{array}$ & $\begin{array}{l}\text { ABCDEg to } \\
\text { ABCDEFg } \\
\text { at } 55 \mathrm{~km} \\
\text { with } \Phi=60^{\circ}\end{array}$ & $\begin{array}{l}\text { ABCDEg to } \\
\text { ABCDEFg } \\
\text { at } 5 \mathrm{~km} \\
\text { with } \Phi=60^{\circ}\end{array}$ & $\begin{array}{l}\text { ABCDEg to } \\
\text { ABCDEFg } \\
\text { at } 33 \mathrm{~km} \\
\text { with } \mathrm{Rf}=0 \Omega\end{array}$ & $\begin{array}{l}\text { ABCDEg to } \\
\text { ABCDEFg } \\
\text { at } 9 \mathrm{~km} \\
\text { with } \mathrm{Rf}=0 \Omega\end{array}$ & $\begin{array}{l}\text { ABCDEg to } \\
\text { ABCDEFg } \\
\text { at } 15 \mathrm{~km} \\
\text { with } \mathrm{Rf}=0 \Omega\end{array}$ \\
\hline Phase A & $\mathrm{La}$ & 63.12 & 55.01 & 5.09 & 33.11 & 9.02 & 15.06 \\
\hline Phase B & $\mathrm{Lb}$ & 63.15 & 54.96 & 5.11 & 33.08 & 9.16 & 14.92 \\
\hline Phase C & Lc & 63.03 & 55.05 & 5.13 & 33.00 & 9.21 & 15.03 \\
\hline Phase D & $\mathrm{Ld}$ & 63.11 & 55.06 & 5.07 & 32.80 & 9.02 & 15.08 \\
\hline Phase E & Le & 63.02 & 55.00 & 5.07 & 33.01 & 9.11 & 15.12 \\
\hline Phase F & Lf & 63.23 & 55.05 & 5.10 & 33.01 & 9.07 & 15.01 \\
\hline
\end{tabular}

\subsection{Comparison with other techniques}

To judge the expediency of the technique, the comparison study has been carried out for maximum deference between actual and measured value of fault location and technique used. The proposed technique has

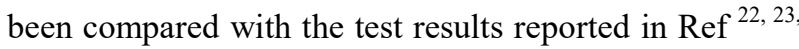
30. The comparison of proposed technique with established methods are shown in table 11. The maximum deference between actual and measured value of fault location estimation in $\operatorname{Ref}^{22,23}$ are $0.459 \mathrm{~km}$ and
$0.468 \mathrm{~km}$ respectively. As revealed from the simulation results, the proposed method raised accurate performance for multi location and transforming phase to ground faults with the maximum deference between actual and measured value of fault location estimation levels of $0.30 \mathrm{~km}$ and $0.34 \mathrm{~km}$ for both cases, respectively. Distance estimation method ${ }^{30}$ for multi location and transforming faults is also developed using ANN. The drawback of the ANN based approach is that it requires training process which requires bulky training samples, training algorithms, number of hidden layers, 
choice of the transfer function, neurons, epochs and setting goal. It is noteworthy to mention that the FIS does not employ large number of training samples however it performs very well and correctly.

Table 11. Comparison of the proposed technique with established methods

\begin{tabular}{|c|c|c|c|c|}
\hline Reference no & 22 & 23 & 30 & Proposed method \\
\hline Inputs used & Voltages and currents & Voltages and currents & Voltages and currents & Only currents \\
\hline Transmission line type & SPT line & SPT line & $\begin{array}{l}\text { Three phase } \\
\text { transmission line }\end{array}$ & SPT line \\
\hline Fault type & Shunt faults & Shunt faults & $\begin{array}{l}\text { Multi location and } \\
\text { transforming faults }\end{array}$ & $\begin{array}{l}\text { Multi location and } \\
\text { transforming faults }\end{array}$ \\
\hline Protection function & $\begin{array}{l}\text { Fault zone identification } \\
\text { and location }\end{array}$ & $\begin{array}{l}\text { Fault detection, } \\
\text { classification and } \\
\text { location }\end{array}$ & Fault location & Fault location \\
\hline Algorithm used & Modular neuro wavelet & $\begin{array}{l}\text { Wavelet and artificial } \\
\text { neural networks }\end{array}$ & $\begin{array}{l}\text { Artificial neural } \\
\text { networks }\end{array}$ & FIS \\
\hline $\begin{array}{c}\text { Maximum difference of } \\
\text { actual and measured } \\
\text { value }\end{array}$ & $0.459 \mathrm{~km}$ & $0.468 \mathrm{~km}$ & $1 \mathrm{~km}$ & $0.34 \mathrm{~km}$ \\
\hline
\end{tabular}

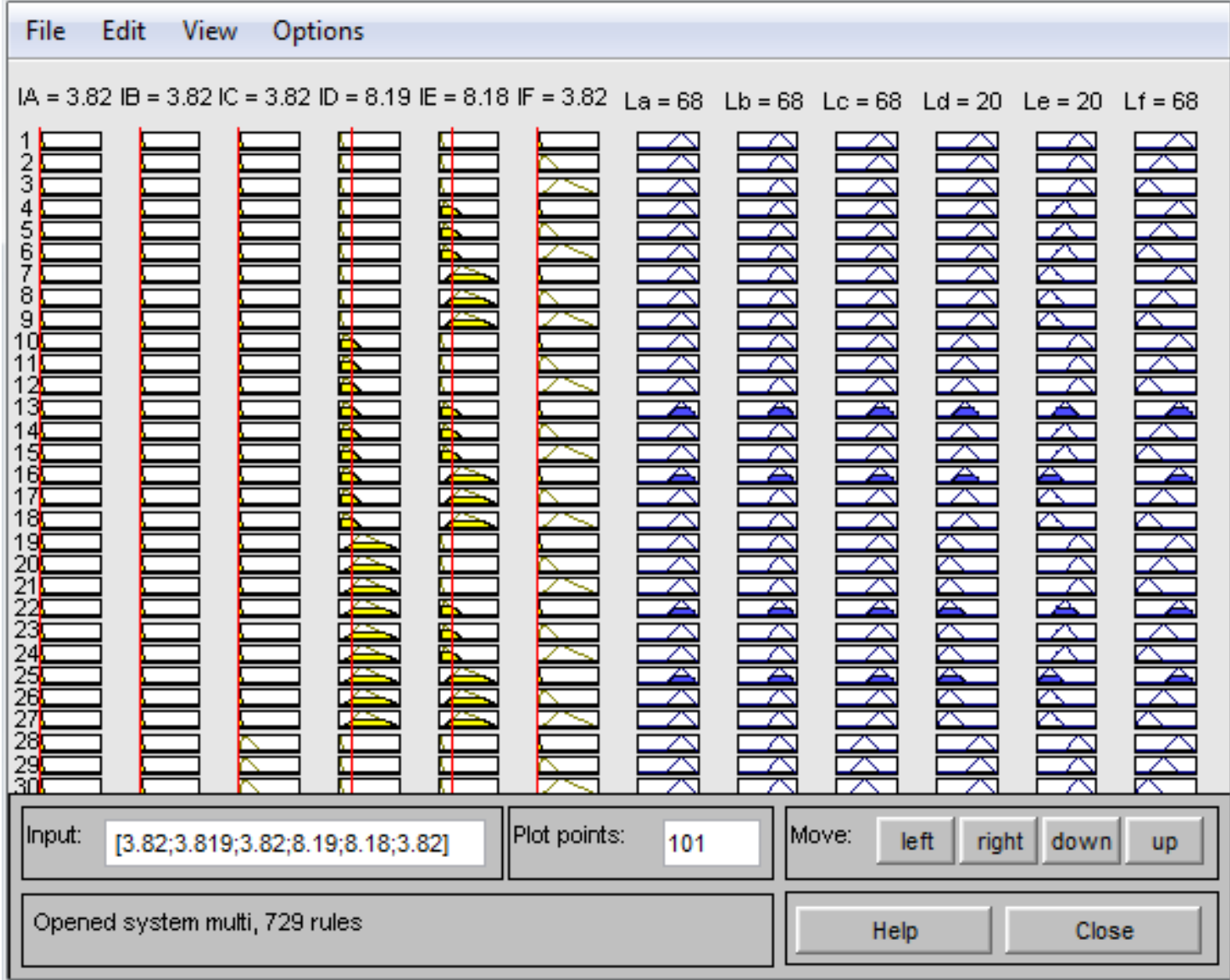

Fig. 10. Evaluation view of FIS output in case of transforming faults 


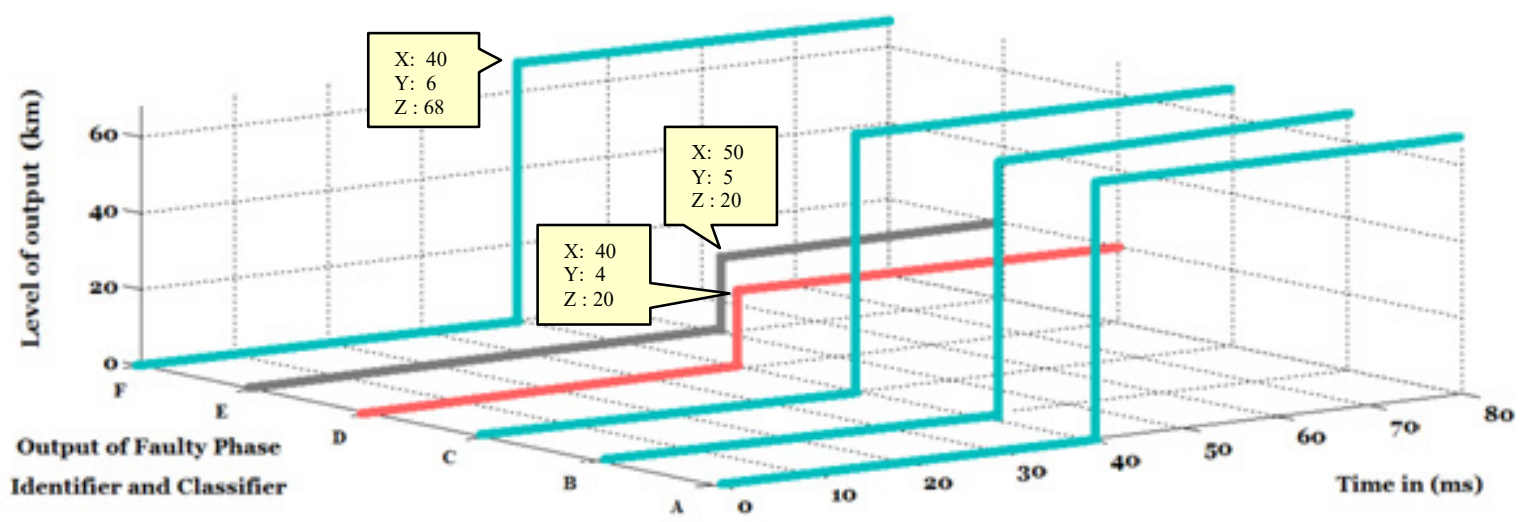

Fig. 11. Classification view of FIS output in case of transforming faults

\section{Conclusion}

A precise fault location method for SPT lines was proposed using FIS and single end currents. DFT is used for pre-processing of the six phase current signals. The fundamental component of currents has been only employed by taking into account for proposed method. The proposed approach does not require any classification method for phase to ground faults classification. Also, the method is independent of the receiving end data. FIS with IF-THEN rules has been arranged for fault location estimation. This facilitated locating all multi location phase to ground fault types including transforming faults successfully. Evaluation studies have discussed that the proposed method can yield accurate estimates under variety of fault conditions for SPT line. In addition, the maximum deference between actual and measured value of fault location does not exceed $0.34 \mathrm{~km}$ in all test cases. The suggested technique based on fuzzy for fault location is promising solution compared with earlier techniques and the test results verify the superiority of the proposed fuzzy based scheme over other schemes for fault location.

\section{References}

1. J.R. Stewart and D.D. Wilson, High phase order transmission-a feasibility analysis part-I- steady state considerations, IEEE Trans. Power Appar Systems. 97(6) (1978) 2300-2307.

2. J.R. Stewart and D.D. Wilson, High phase order transmission-a feasibility analysis part-II- over voltages and insulation requirements, IEEE Trans. Power Appar Systems. 97(6) (1978) 2308-2317.

3. J.R. Stewart and I.S. Grant, High phase-order ready for applications, IEEE Trans. Power Appar Systems. 101(6) (1982) $1757-1767$

4. J.R. Stewart, E. Kallaur and I.S. Grant, Economics of EHV high phase order transmission, IEEE Trans. Power Appar Systems. 103(11) (1984) 3386-3392.

5. J.R. Stewart, L.J. Oppel, G.C. Thomann, T.F. Dorazio and M.T. Brown, Insulation coordination, environmental and system analysis of existing double circuit line reconfigured into six phase operation, IEEE Trans. Power Delivery. 7(3) (1992) 1628-1633.

6. S.S. Venkata, W.C. Guyker, B.H. Booth, J. Kondramgunta, N.B. Bhatt and N.K. Saini, EPPC-A computer program for six phase transmission line design, IEEE Trans. Power Appar Systems. 101(7) (1982) 1859-1869.

7. W. Mustafa, M.R. Ahmad and H. Sharif, Fault analysis on double three-phase to six-phase converted transmission line, in Proceedings of IEEE Power Engineering Conference. (Singapore, 2005).

8. L. Oppel and E. Krizauskas, Evolution of the performance of line protection schemes on the NYSEG six phase transmission system, IEEE Trans. Power Delivery. 14(1) (1999) 110-115.

9. A.P. Apostolov and R.G. Raffensperger, Relay protection operation for faults on NYSEG's six-phase transmission line, IEEE Trans. Power Delivery. 11(1) (1996) 191-196.

10. A. Apostolov and W.George, Protecting NYSEG's sixphase transmission line, IEEE Computer Applications in Power. 5(4) (1992) 33-36.

11. W.S. Abu-elhaija and F.K. Amoura, Fault analysis of six phase power system using six phase symmetrical components, Electric Power Components and Systems. 33(6) (2006) 657-671.

12. N.B. Bhatt, S.S. Venkata, W.C, Guyker, and B.H. Booth, Six-phase (multi-phase) power transmission systems: fault analysis, IEEE Trans. Power Appar Systems. 96(3) (1977) 758-767. 
13. S.S. Venkata, W.C. Guyker, B.H. Booth, J. Kondramgunta, N.K. Saini and E.K Stanek,138-kV, Six phase transmission system: fault analysis, IEEE Trans. Power Appar Systems. 101(5) (1982) 1203-1218.

14. B.K. Bhut and R.D. Sharma, Analysis of simultaneous ground and phase faults on a six phase power system, IEEE Trans. Power Delivery. 4(3) (1989) 1610-1616.

15. K. Gayathri and N. Kumarappan, Double circuit EHV transmission lines fault location with RBF based support vector machine and reconstructed input scaled conjugate gradient based neural network, International Journal of Computational Intelligence Systems, 8(1) (2015) 95-105.

16. Aleena Swetapadma and Anamika Yadav, A novel decision tree regression-based fault distance estimation scheme for transmission lines, IEEE Trans. Power Delivery. 32(1) (2017) 234-245.

17. Pramote Chaiwan, Ning Kang and Yuan Liao, New accurate fault location algorithm for parallel transmission lines using local measurements, Electric Power Systems Research. 108 (2014) 68-73.

18. Sami Ekici, Support vector machines for classification and locating faults on transmission lines, Applied Soft Computing. 12(6) (2012) 1650-1658.

19. Rounak Meyur and D.K. Mohanta, A wavelet-adaptive network based fuzzy inference system for location of faults in parallel transmission lines, IEEE International Conference on Power Electronics, Drives and Energy Systems. (Trivandrum, India, 2016).

20. Simi P Valsan and K Shanti Swarup, High speed fault classification in power lines: theory and FPGA based implementation, IEEE Trans. Industrial Electronics. 56(5) (2009) 1793-1800.

21. L.N. Tripaty, P.K. Dash and S.R. Samantary, A new cross- differential protection scheme for parallel transmission lines including UPFC, IEEE Trans. Power Delivery. 29(4) (2014) 1822-1830.

22. Ebha Koley, Khushaboo Verma and Subhojit Ghosh, A modular neuro-wavelet based non-unit protection scheme for zone identification and fault location in six phase transmission line, Neural Computing and Applications. 28(6) (2017) 1369-1385.

23. Ebha Koley, Khushaboo Verma and Subhojit Ghosh, An improved fault detection classification and fault location scheme based on wavelet transform and artificial neural networks for six phase transmission line using single end data only, Springer Plus. (2015).

24. J.E. Stamp and A.A. Girgis, Fault location technique for six phase transmission lines with unsynchronized phasors, in Proceedings of IEEE Conference on Transmission and Distribution. (New Orleans, LA, USA, 1999).

25. J.E. Stamp and A.A. Girgis, Fault location and phase selection for UHV six-phase transmission lines, in Proceedings of IEEE Asia Pacific Power and Energy Engineering Conference. (China, 2011).
26. Z.Y. Xu, W. Li, T.S. Bi, G. Xu and Q.X. Yang, Firstzone distance relaying algorithm of parallel transmission lines for cross-country nonearthed faults, IEEE Trans. Power Delivery. 26(4) (2011) 2486-2494.

27. Tianshu Bi, Wei Li, Zhenyu Xu and Qixun Yang, Firstzone distance relaying algorithm of parallel transmission lines for cross-country grounded faults, IEEE Trans. Power Delivery. 27(4) (2012) 2185-2592.

28. Aleena Swetapadma and Anamika Yadav, Directional relaying using support vector machine for double circuit transmission lines including cross-country and intercircuit faults, International Journal of Electrical Power and Energy Systems. 81 (2016) 254-264.

29. Aleena Swetapadma and Anamika Yadav, All shunt fault location including cross-country and evolving faults in transmission lines without fault type classification, Electric Power Systems Research. 123 (2015) 1-12.

30. Aleena Swetapadma and Anamika Yadav, Improved fault location algorithm for multi-location faults, transforming faults and shunt faults in thyristor controlled series capacitor compensated transmission lines, IET Generation, Transmission and Distribution. 9(13) (2015) $1-12$.

31. J. Uday Bhaskar, S.K. Abdul Gafoor and J. Amarnath, Wavelet fuzzy based fault location estimation in a three terminal transmission system, in Proceedings of International Conference on Advanced Computing and Communication Systems. (Coimbatore, India, 2015).

32. Anamika Yadav and Aleena Swetapadma, Enhancing the performance of transmission line directional relaying, fault classification and fault location schemes using fuzzy inference systems, IET Generation, Transmission and Distribution. 9(6) (2015) 580-591.

\section{Appendix A.}

\begin{tabular}{lcc}
\hline Parameter & Units & Values \\
\hline Number of Circuits & - & 1 \\
Number of Phases & - & 6 \\
Source Voltage & {$[\mathrm{kV}]$} & 138 \\
Base Voltage & {$[\mathrm{kV}]$} & 138 \\
Base Power & {$[\mathrm{MVA}]$} & 100 \\
Frequency & {$[\mathrm{Hz}]$} & 60 \\
Earth Resistivity & {$[\Omega-\mathrm{m}]$} & 100 \\
Line Length & {$[\mathrm{km}]$} & 68 \\
Short Circuit Capacity & {$[\mathrm{MVA}]$} & 1250 \\
Source X/R Ratio & - & 10 \\
& {$[\mathrm{~kW}]$} & 100 \\
Load at Bus & {$[\mathrm{kVAR}]$} & 100 \\
\hline
\end{tabular}

